\title{
Late Devonian (Famennian) conodonts from Baqer-Abad section, northeast Isfahan province, Central Iran
}

\author{
Conodontos del Devónico tardío (Fameniano) de la sección Bager-Abad, noreste de \\ Isfahan, Irán central
}

Ali Bahrami ${ }^{1, *}$, Ayesheh Parast ${ }^{1}$, Iliana Boncheva ${ }^{2}$, Mehdi Yazdi $^{1}$

${ }^{1}$ Department of Geology, Faculty of Sciences, University of Isfahan, Plaza Azadi, 81744, Isfahan, Iran.

${ }^{2}$ Geological Institute, Bulgarian Academy of Sciences, Bonchev st. bl.24,1113, Sofia, Bulgaria.

* Corresponding author: (A. Bahrami) bahrami_geo@yahoo.com

\section{ABSTRACT}

The Baqer-Abad section, northeast Isfahan Province, Central Iran has a thickness of $220 \mathrm{~m}$ representing mainly shallow-water palaeoenvironments with fossiliferous abundance and biodiversity. The zonal division in this section includes ten Famennian zones as follows, from the bottom to the top: triangularis Zone, crepida Zone, Lower rhomboidea Zone, gracilis-Lower marginifera interval Zone, Upper marginifera barren Zone, Uppermost marginifera-trachytera interval Zone, postera Zone, Lower expansa Zone, Middle expansa Zone, Upper expansa-praesulcata interval Zone. This section comprises the most complete biozonation of the Famennian stage in the area of northeast Isfahan in Central Iran. The analysis of the conodont associations and biofacies support the interpretation that these shallow-water habitats were still in platform conditions. Based on the conodont record, major stratigraphic gaps also occur at the end of Famennian, which confirms earlier results reported from other sections with similar palaeoenvironments in the North Isfahan area.

Keywords: Late Devonian, Famennian, Bahram Formation, Conodonts, Central Iran,Isfahan.

\section{RESUMEN}

La sección Baqer-Abad tiene un espesor de 220 m y está representada principalmente por paleoambientes de aguas someras son abundantes fósiles $y$ biodiversidad. La división zonal en esta sección incluye diez biozonas del Fameniano, que son, de base a techo: Zona de triangularis, Zona de crepida, Zona Inferior de rhomboidea, intervalo Zona Superior de rhomboidea-Zona Inferior de marginifera, Zona Superior de marginifera (estéril), intervalo Zona Más Superior de marginifera-Zona de trachytera, Zona de postera, Zona Inferior de expansa, Zona Media de expansa, Zona Superior de expansa-praesulcata intervalo Zona. Esta sección comprende la biozonación más completa del piso Fameniano en el área al noreste de Isfahan en Irán Central. El análisis de las asociaciones de conodontos y sus biofacies sostiene la interpretación de que estos hábitats de aguas someras estaban todavia en condiciones de plataforma. Con base en el registro de conodontos se puede inferir la presencia de importantes lagunas estratigráficas que tuvieron lugar al final del Fameniano, lo cual confirma resultados anteriores reportados en otras secciones con paleoambientes similares en el área del norte de Isfahan.

Palabras clave: Devónico Superior, Fameniano, Formación Bahram, Conodontos, Irán central, Isfahan.
Peer Reviewing under the responsibility of Universidad Nacional Autónoma de México. 


\section{Introduction}

The Iranian Plate is regarded as a marginal fragment of Gondwana, which was separated from the Gondwanan-Arabian plate during the late Paleozoic or Early Triassic and was connected with the Eurasian Turan Plate by the end of Middle Triassic (Stöcklin, 1968; Berberian and King, 1981; Soffel and Förster, 1984; Weddige, 1984a, 1984b; Scotese, 2001). Middle to Upper Devonian strata mainly indicate shallow-water facies and occur in isolated units in central Iran (e.g., Zahedi, 1973; Soffel and Förster, 1984; Wendt et al., 2005). The distribution of the upper Paleozoic sedimentary rocks around Isfahan are mostly limited to the northern Isfahan basin (Soh and Natanz regions: Najhaf, Negheleh, Varkamar, Northern Tar and Western Kesheh sections; Zahedi, 1973; Adhamian, 2003; Ghobadipour et al., 2013; Bahrami et al., 2015), northeastern Isfahan basin (Zefreh, Chahriseh, and Dizlu sections; Brice et al., 2006; Gholamalian, 2003; Habibi et al., 2013, Koenigshof et al., 2017, Ernst et al., 2017, Bahrami et al., 2018), and southern Isfahan basin (Darchaleh and Ramsheh, in Shahreza region, sections; Boncheva et al., 2007; Leven and Gorgij, 2008; 201 la, 201 lb; Bahrami et al., 2014).

The most complete Paleozoic sedimentary sequence is located $55 \mathrm{~km}$ northeast of Isfahan, southwest of the Chahriseh Village in Kaftari Mountain at coordinates $32^{\circ} 59^{\prime} 13^{\prime \prime} \mathrm{N}, 52^{\circ} 03^{\prime} 44^{\prime \prime} \mathrm{E}$; it can be found on a 1:100000 Map of Kouhpayeh (Radfar and Kohansal, 2002). The studied sedimentary sequences were explored for the first time during the 1970s (Djafarian and Brice, 1973; Zahedi, 1976). In subsequent years, considering that Chahriseh (Kaftar Mountain) section is one of the best Upper Devonian sections in western central Iran, the mentioned fossiliferous section was noticed by several paleontological and sedimentological studies (e.g., Shirani, 1995; Hamedani, 1996; Djafarian 2000; Brice and Kebriae, 2000; Mistiean et al., 2000; Mistian and Gholamalian, 2000; Yazdi et al., 2000; Hairapetian et al., 2000; Ghavidel-syooki, 2001; Turner et al., 2002; Safari and Kangazian, 2003; Gholamalian, 2003, 2007; Webster et al., 2007). These investigations showed that the age of this sedimentary sequence ranges from the early Frasnian to the late Famennian, beginning with some shallow-water carbonate horizons that gradually change to thick-bedded clastic deposits and shallow-water carbonate, with shale layers (Yazdi et al., 2000; Gholamalian, 2003). Upper Devonian beds of all the studied profiles at North Isfahan basin are overlain unconformably by covered by the carbonate-clastic Permian sequence (Gholamalian, 1998; Yazdi et al., 2000). This erosional gap, which is reported in most parts of the Iranian platform as the "Hercynian unconformity" (Wendt et al., 2002, 2005), probably has been associated with the Hercynian onset of events (Berberian and King, 1981). On the basis of other hypotheses, this event may be the result of deformation and uplifting in the primary phase prior to the compressive subduction along the northern margin of Gondwana, and in the Paleotethys just before the opening of the Neotethys rift during the middle Permian (Sharland et al., 2001; Ruban et al., 2007).

The oldest Paleozoic sedimentary rocks in the Chahriseh region are composed of shallow-water clastic and carbonate sequences of early Frasnian age. They are mainly composed of thin-bedded limestone, sandstone, brecciated horizons, and, to a lesser extent, sandy limestone and dolomite; the thickness of this unit is $220 \mathrm{~m}$ (Gholamalian, 1997). The upper carbonate unit is mostly composed of carbonate beds including various epifaunal groups such as rugose and tabulata corals, and stromatoporida biostromes accompanied with sandstone and interbedded shales; the thickness of this unit is $185 \mathrm{~m}$ (Gholamalian, 1997). The biostrome-bearing Frasnian horizons (Yazdi, 1996), which form two key beds in the Chahriseh region, are generally found in other Frasnian sequences of Iran. The age of the lower part of this unit is identified to be middle Frasnian to late Frasnian (jamieae Zone-rhenana Zone) and the age of the upper part is attributed to late Frasnian to early Famennian (linguiformis Zone-triangularis Zone) (Gholamalian, 
1997, 1998; Gholamalian et al., 2000). On this interval, there are Famennian deposits with an approximate thickness of $100 \mathrm{~m}$, which are composed of clastic and carbonate parts, 40 and 60 m thick, respectively (Gholamalian, 1998). The lithology of the clastic part includes shale and sandstone with carbonate intercalations, and the carbonate part is composed of limestone, dolomitic limestone, marly limestone, and marl.

The carbonate part is attributed to early Famennian to late Famennian (triangularis Zone-Early praesulcata Zone) (Mistiaen et al., 2000), and could be considered as an equivalent of the Shishtu I section (Gholamalian, 2007). According to Yazdi et al. (2000), however, and based on conodonts, the expansa zone is related to the Late Famennian.
The objectives of this paper are to describe and interpret the reconstruction of the paleoenvironment and precise age assignment of Bahram Formation in Baqer-abad section at northeastern Isfahan basin in order to provide complementary evidence exhibits a number of different lithologies, such as dolostone, limestone, quarzitic sandstone, and shale with different faunal assemblages, which point to a shallow-water shelf setting in Late Devonian of Iran, and also to show the different lithologies and the time interval differences of Bahram Formation are related to lateral facies changes and/or synsedimentary vertical movements in the Palaeozoic, which were associated with horst-andgraben structures in different tectonic blocks of the country.

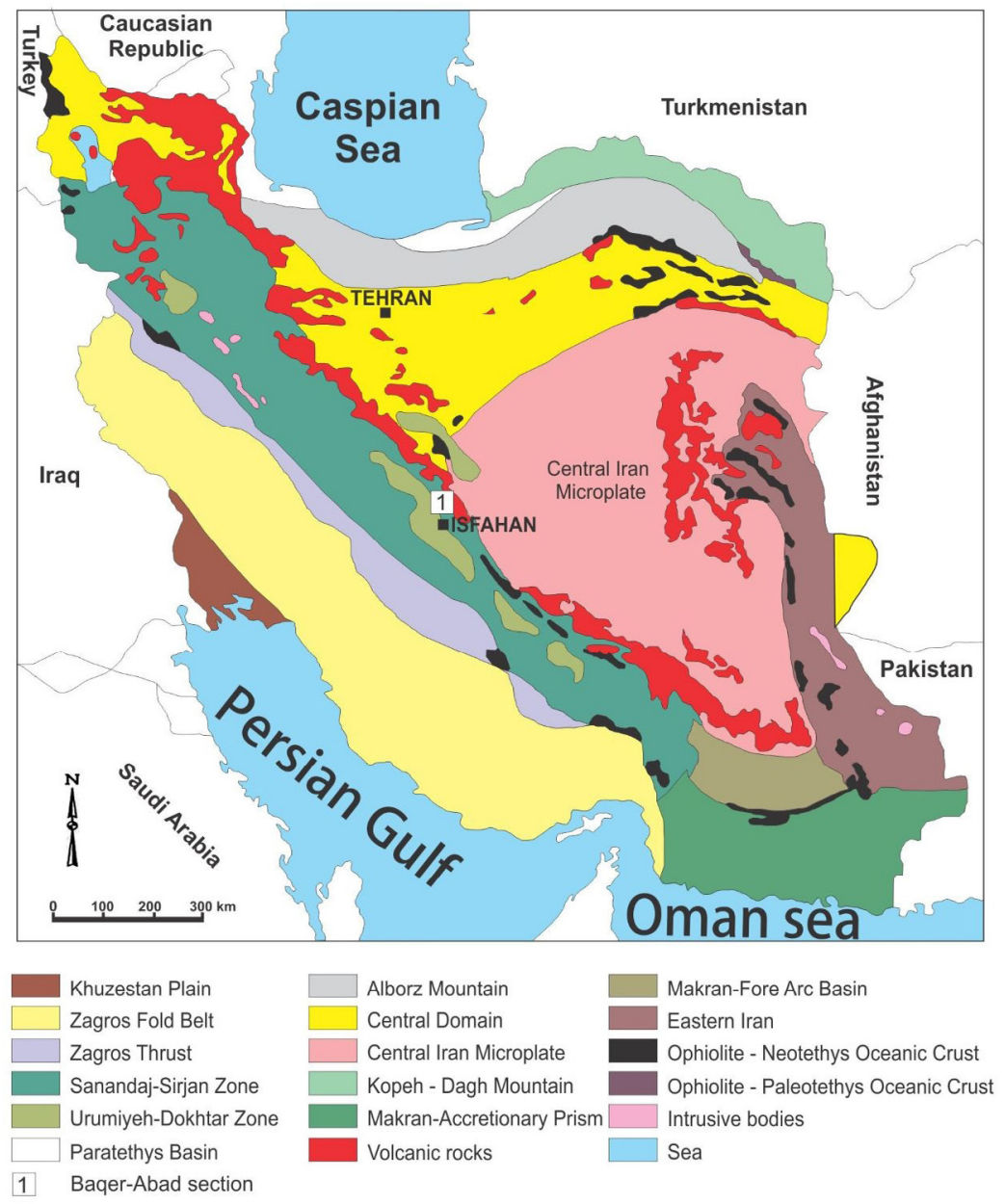




\section{Geological setting}

The Baqer-Abad section is located $46 \mathrm{~km}$ north-

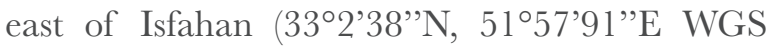
coordinates; Figures 1 and 2) where most Devonian outcrops are exposed; the sequence includes some hiatuses due to erosion and/or tectonic activity (Figure 3). The entire section has a thickness of approximately $1000 \mathrm{~m}$, ranging in age from the Devonian (Bahram Formation) to the Lower Cretaceous (still not named officially). The studied portion of the Bahram Formation has a thickness of $220 \mathrm{~m}$, representing mainly shallow-water palaeoenvironments.

\section{Lithology}

Based on field observations and sedimentological characteristics, the section was grouped in 13 units, which are plainly described below, from base to top:
Package 1 - samples P1-P7 - The base of the section is composed of $33 \mathrm{~m}$ thick grey, mediumto thick-bedded limestone. The limestone is rich in fauna, such as brachiopods, fragmented corals, crinoid stems, tentaculites, and algal patches with a few prominent distinct bryozoan horizons. This unit changes to a yellow dolomitic limestone at the top.

Package 2 - samples P8-P12 - Grey, mediumto thick-bedded sandy limestone (25 m) including brachiopod debris, current directed brachiopod shell and tentaculites in a few distinct levels.

Package 3 - The following $8 \mathrm{~m}$ are composed of cross-bedded sandstone with weathered ichnofossils.

Package 4 - sample P13 - Thin unit of $4 \mathrm{~m}$, medium- to thick-bedded limestone with scarce fossil content.

Package 5 - Thin cross-bedded quarzitic sandstone $3 \mathrm{~m}$ thick.

Package 6 - samples P14-P15 - Thick- to medium-bedded fossiliferous grey limestone with scattered brachiopods, corals, and tentaculits, $35 \mathrm{~m}$ thick.
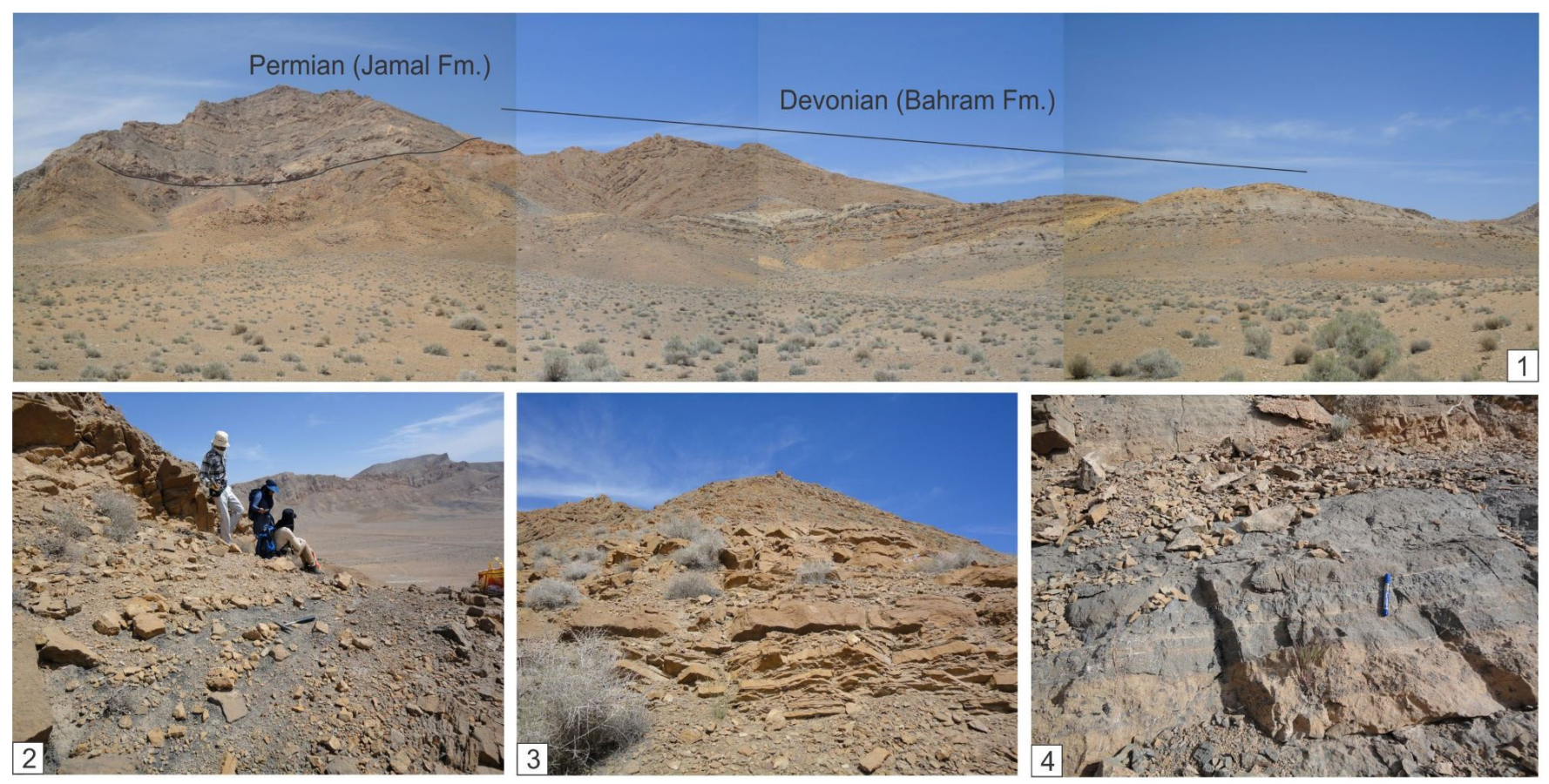

Figure 2 Representative examples of different shallow-water sediments from the investigated sections. (1) Panoramic view of the Baqer-Abad section. (2) Grey to black shale (package 8, Figure 4) at the upper part of the studied profile. (3) Sandy dolomitic limestone (see package 7, Figure 4). (4) Alternation of yellow to grey limestone with algal contents (upper part of package 1, see Figure 4). 
Package 7-samples P16-P18 - Thin-bedded fossiliferous grey limestone with abundant brachiopods, corals, gastropods, and tentaculites, $35 \mathrm{~m}$ thick.

Package 8 - Grey to black platy shale with no fossil content, $5 \mathrm{~m}$ thick.

Package 9 - samples P19-P20 - Thin-bedded fossiliferous grey sandy limestone with abundant brachiopods, corals, gastropods, and tentaculites, $35 \mathrm{~m}$ thick.

Package 10 - samples P21-P29 - Thick- to medium-bedded fossiliferous grey limestone with alternation of grey to green shale, including brachiopod, coral, crinoid stem, gastropod, and tentaculite, $38 \mathrm{~m}$ thick.
Package 11 - Grey to green platy shale including very rare weathered brachiopod, $8 \mathrm{~m}$ thick.

Package 12 - Grey fine-grained sandstone including rare scattered brachiopod and crinoid stem, $8 \mathrm{~m}$ thick.

Package 13 - The uppermost part of the Bahram Formation is composed of medium-bedded dolomitic limestone with gastropod, brachiopod, and very rare coral segments, $5 \mathrm{~m}$ thick.

The Devonian strata are disconformably overlain by red marly sandstone, limestone, and dolomitic limestone of the Permian Jamal Formation. (Figure 4).

\begin{tabular}{|c|c|c|c|}
\hline \multicolumn{2}{|c|}{ TIME } & SYMBOI & LITHOLOGY \\
\hline \multirow{4}{*}{$\begin{array}{l}0 \\
\text { O } \\
\text { O } \\
\text { D } \\
0\end{array}$} & \multirow{3}{*}{ 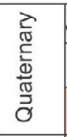 } & $\because Q_{a}^{\circ}:$ & Recent alluvium, river deposite \\
\hline & & $Q^{13}$ & Recent terraces \\
\hline & & $Q^{12}$ & old terraces \\
\hline & 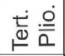 & $\mathrm{Pl}$ & Conglomerate and argilaceous sandstone \\
\hline \multirow{8}{*}{$\begin{array}{l}0 \\
\text { O } \\
\text { O } \\
\mathbb{0} \\
\Sigma\end{array}$} & $\stackrel{\infty}{כ}$ & & Marl with orbitolina, and ammonite \\
\hline & 岕 & $\mathrm{K}_{2}^{\prime}$ & $\begin{array}{l}\text { Limestone with orbitolina, silty shale and sandy } \\
\text { limestone locally }\end{array}$ \\
\hline & Uँ & $K_{1}$ & Conglomerate and red sandstone \\
\hline & 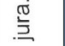 & $\mathrm{J}_{1}$ & Shale and sandstone with ammonite limestone intercalation \\
\hline & \multirow{4}{*}{ 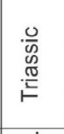 } & $\mathrm{T}_{4}$ & Heterastridium limestone \\
\hline & & $\mathrm{T}_{3}$ & Shale with intercalations of sandstone and ammonite limestone \\
\hline & & $\mathrm{T}_{2}$ & Yellowish dolostone with intercalation of white limestone at the top. \\
\hline & & $\mathrm{T}_{1}$ & Red nodular and bauxitic sandstone and shale \\
\hline \multirow{2}{*}{$\begin{array}{l}\frac{0}{0} \\
0 \\
0 \\
\frac{\Phi}{00} \\
0\end{array}$} & 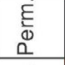 & $P_{j}$ & Dark limestone and dolostone with fusulinid \\
\hline & 㐫 & $D_{b}$ & Limestone and dolostone with brachiopod and bryozoan \\
\hline
\end{tabular}
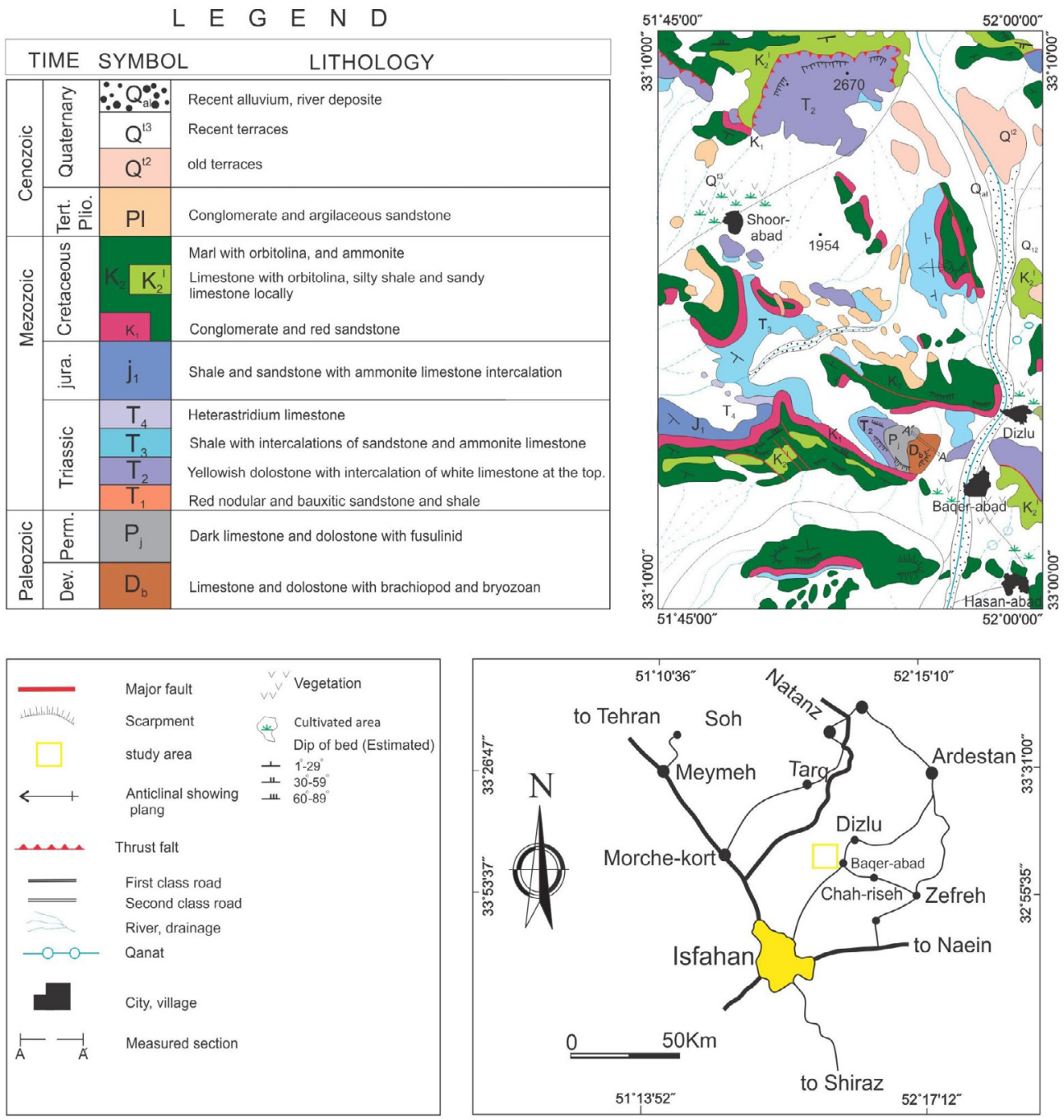

Figure 3 Geological map of the Baqer-Abad area after Zahedi (1976) with position of the investigated section northeast of Isfahan and the accessible roads. 


\section{Material and methods}

In order to improve the knowledge of the biostratigraphy of the Baqer-Abad section, 31 samples, approximately 3 to $4 \mathrm{~kg}$ each, were taken from the carbonates and processed by conventional methods using $10 \%$ acetic or formic acid. Washed residues were sieved, separated into three fractions, and conodonts were handpicked utilizing a microscope. The extracted conodonts are stored at the department of geology (sample numbers: EUIC), University of Isfahan, I.R. Iran. Repository numbers are given in the figure captions, see Appendix.

The carbonates yielded more than 1410 conodont elements, which provided the stratigraphic framework of the Bahram Formation in the BaqerAbad section (Figure 7). Conodont associations show high diversity and exhibit some important zonal index taxa of the widely applied conodont standard zonation (Klapper and Ziegler 1979; Ziegler and Sandberg 1990; Clausen et al., 1993). The state of preservation of conodonts is good; the color alteration index is beyond the diagenetic stage (CAI 4.5-5). Sedimentological units of the section are briefly described in a stratigraphic order based on facies changes observed in the field as a detailed microfacies analysis is not the aim of this paper.

\section{Biozonal division of Baqer-Abad section}

\subsection{TRIANGULARIS ZONE}

The triangularis Zone is represented by low diversity of conodont association. The fauna of this zone has been recorded in medium- to thick-bedded limestones from package 1 comprising the first $20 \mathrm{~m}$ (samples P1-P5) and contains typical conodont associations for the triangularis Zone (Lower Famennian). The lower boundary of this zone is recognized by the first appearance of the index taxon Palmatolepis triangularis. The accompanying taxa from package 1 are Icriodus alternatus alternatus, Icriodus iowaensis iowaensis, and Polygnathus procerus appearing in the upper part of the zone and ranging through the following zone. Palmatolepis perlobata perlobata, Palmatolepis tenuipunctata, Polygnathus brevilamunus, and Icriodus iowaensis iowaensis have their first occurrence at the upper limit of the triangularis Zone, continue through the crepida Zone, and disappear before the lower rhomboidea Zone. Only Palmatolepis triangularis disappears within the Lower crepida Zone, all other conodonts from zonal association continue into the crepida Zone. Ecology: The platform elements in this fauna show that $80 \%$ are species of palmatolepids, $10 \%$ are polygnathids and the remaining $10 \%$ consist of icriodontids and pelekysgnathids. The host limestone of the triangularis zone is rich in fauna, such as brachiopods, fragmented corals, crinoid stems, and tentaculites, with a few prominent distinct bryozoan horizons. Pelagic palmatolepids, but also the rich macrofauna, point to sublitoral palaeoenvironments - mid ramp (Figure 6).

\subsection{CREPIDA ZONE}

The deposits comprising the uppermost part of package 1, yellow dolomitic limestone, and the lowermost part of package 2, medium- to thick-bedded sandy limestone with tentaculites as well as brachiopod debris and shells, are related to the crepida Zone, and conformably overlie the triangularis Zone (from 20 to $40 \mathrm{~m}$ from the base of the section) (samples P5-P9). The lower limit of the crepida Zone in the studied section is defined by the first occurrence of Palmatolepis perlobata perlobata, Palmatolepis tenuipunctata, and Polygnathus brevilaminus. These species mark the upper boundary of the triangularis Zone and the lower boundary of the crepida Zone. Palmatolepis quadrantinodosalobata, Palmatolepis subperlobata, Palmatolepis minuta minuta, and Palmatolepis minuta loba have their first occurrence at the uppermost part of the crepida zone and disappear at its upper boundary serving for delimitation of the upper limit of the crepida zone and the lower boundary of overlying rhomboidea Zone. The upper boundary of the crepida zone is recognized also with the disappearance of Icriodus alternatus alternatus and Icriodus iowaensis iowaensis. The lack 


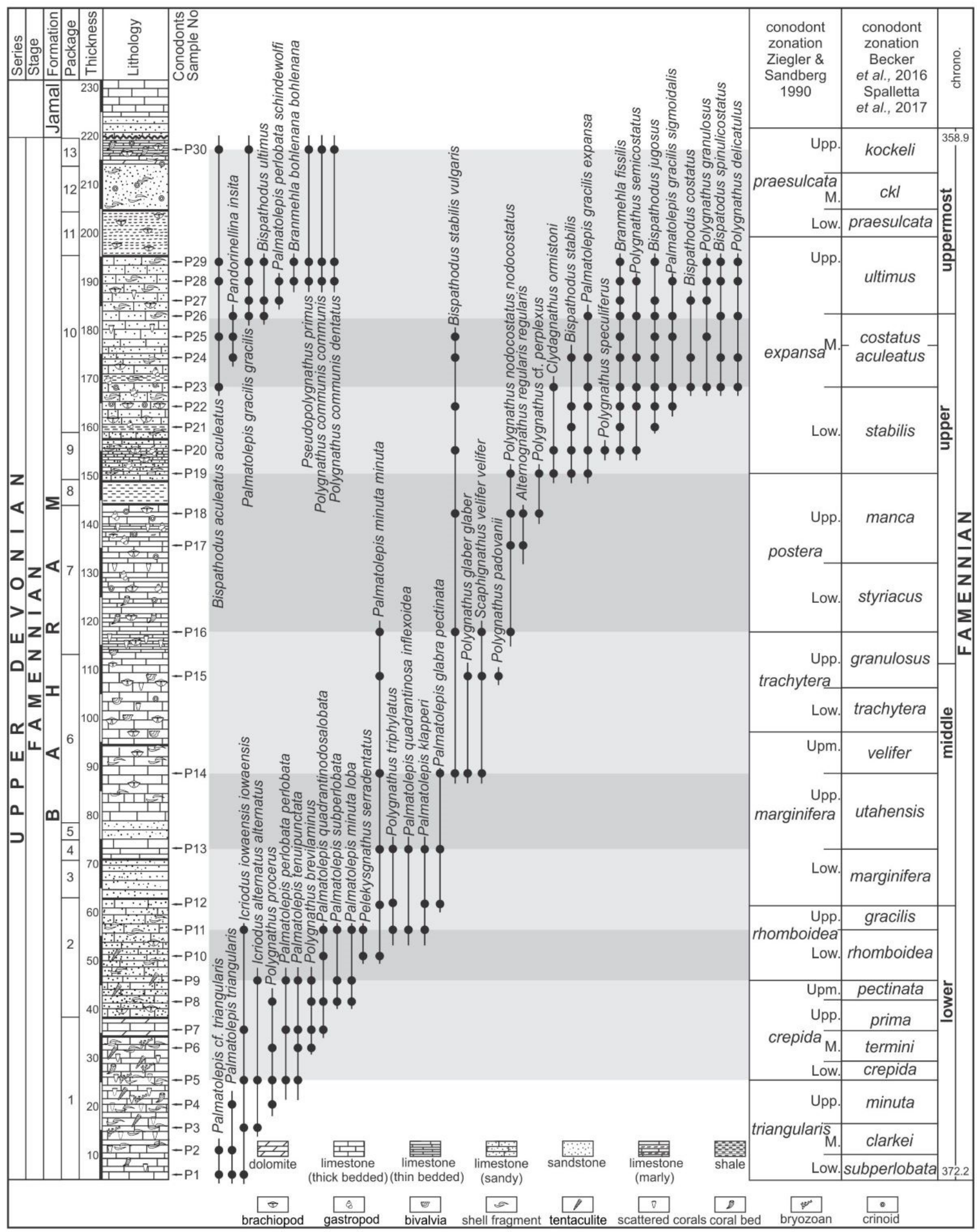


of the key index taxon Palmatolepis crepida gives us a reason to use other species with occurrence at the base of the zone for age determination. The dominant presence of palmatolepids and negligible amount of icriodontids, only transit ranging Icriodus alternatus alternatus and Icriodus iowaensis iowaensis can be interpreted as characteristic conditions of deep water environments. Ecology: The lower part of the section was deposited in the same environment - deep shelf water in the photic zone. According to Flügel (2004), current brachiopods are also found in temperate and cool waters with normal salinity. The dominance of brachiopods in this interval corresponds to a lagoon environment (Figure 6).

\subsection{LOWER RHOMBOIDEA ZONE}

The low diversity, lack of keytaxa and scarce species composition in the interval between 40 and $60 \mathrm{~m}$ from the base of the section in package 2 - upper part of thick-bedded sandy limestones with brachiopod shells (samples P9-P11) do not allow detailing biozonation for the Lower rhomboidea Zone. The lower boundary of this biozone is recognized by the last occurrences of Palmatolepis perlobata perlobata, Palmatolepis tenuipunctata, Polygnathus brevilamunus, Icriodus iowaensis iowaensis, and Icriodus alternatus alternatus, since they have not been reported from beds younger than the latest crepida Zone.

The upper boundary of the Lower rhomboidea Zone is indicated by the last appearance of Polygnathus triphylatus, Palmatolepis quadrantinodosa inflexoidea, Palmatolepis klapperi, Palmatolepis quadrantinodosalobata, Palmatolepis subperlobata, and Palmatolepis minuta loba. Ecology: The sedimentation of the Lower rhomboidea Zone is related to shallow water environments mainly by the presence of sandy limestones. The presence of polygnathids and palmatolepids as indicators for deeper water conditions could be interpreted as an inner ramp to shoal (Figure 6).

\subsection{UPPER RHOMBOIDEA-LOWER MARGINIFERA INTERVAL ZONE}

Upper rhomboidea-Lower marginifera Zone comprises deposits from the uppermost part of package 2 and cross-bedded sandstone with weathered ichnofossils of package 3, from 60 to $75 \mathrm{~m}$ (samples P11-P13). This interval does not contain key-taxon but is defined by characteristic species appearing in this interval. The lower boundary of the Upper rhomboidea-Lower marginifera Zone is indicated by the last occurrence of taxa Palmatolepis quadrantinodosalobata, Palmatolepis subperlobata, and Palmatolepis minuta loba, which serves as indicator of the upper boundary of the underlying zone. The first appearance of Palmatolepis minuta minuta, Polygnathus triphylatus, Palmatolepis quadrantinodosa inflexoidea, and Palmatolepis klapperi, which appear only in this zone in the studied section and disappear at the end of the Upper marginifera Zone, serving as indicators of the upper boundary of the Upper rhomboidea-Lower marginifera Zone interval biozone. Ecology: Conodont biofacies contains palmatolepids and polygnathids related to inner ramp environment - shoal water conditions (Figure 6).

\subsection{UPPER MARGINIFERA ZONE (BARREN)}

This is a typically barren zone with extremely poor content of conodonts and only few transitional specimens. The strata of package 4 and the lower part of package 6 comprise medium- to thick-bedded limestone with scarce fossil contents. The thin cross-bedded quarzitic sandstone of package 5 occupies the interval between 75 and $95 \mathrm{~m}$ (samples P13-P14) from the base of the section, which is situated between well-documented underlying and overlying zones. The lower boundary of this barren zone is marked by the upper boundary of the Upper rhomboidea-Lower marginifera interval Zone, and the upper boundary is marked by the first appearance of Bispathodus stabilis vulgaris, 

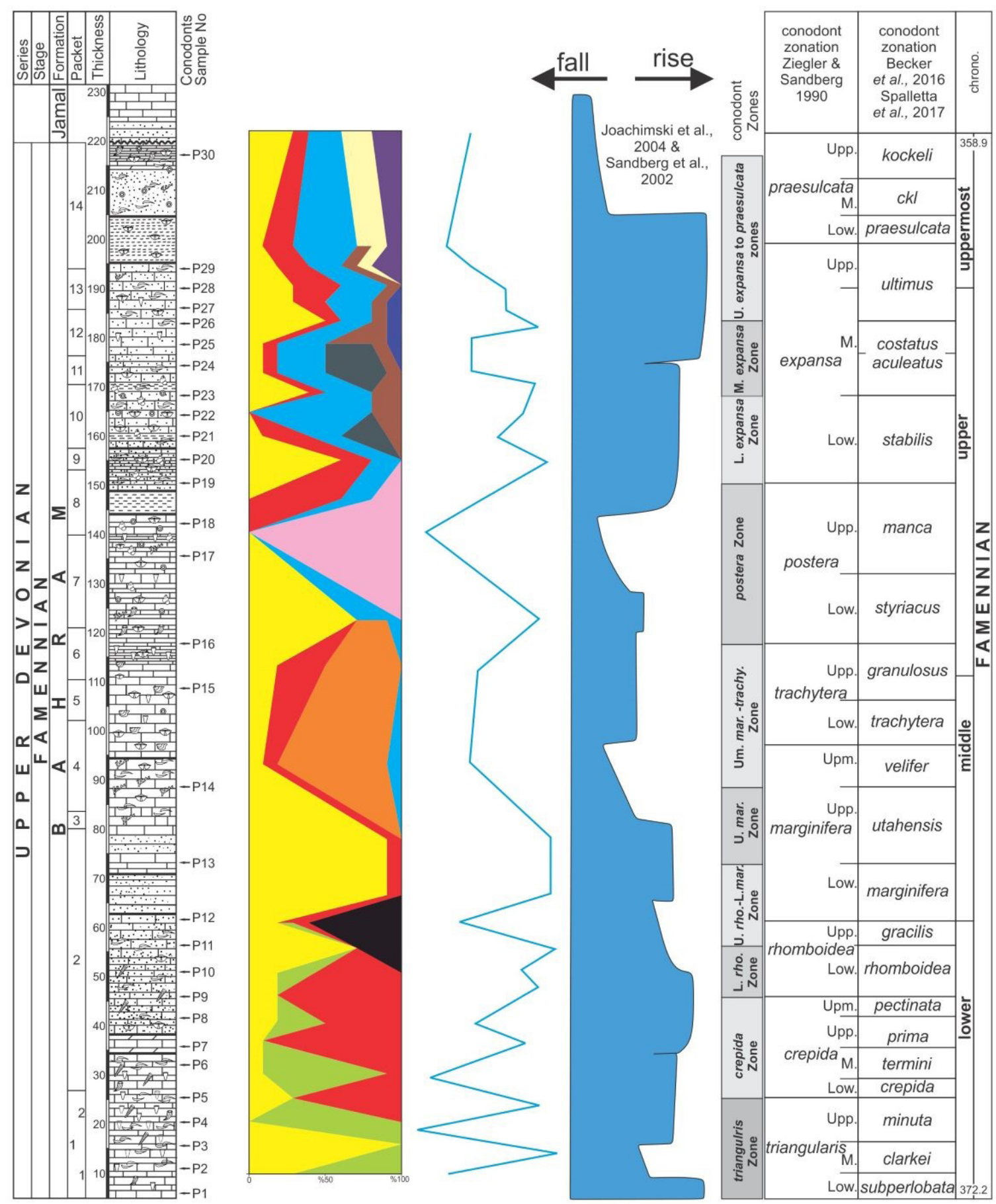

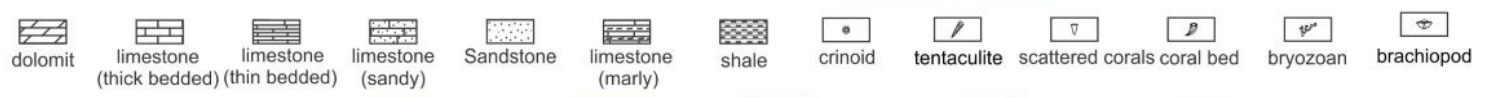

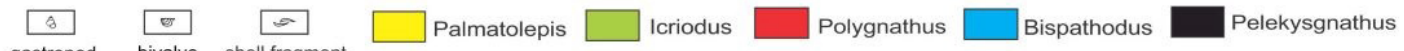
gastropod bivalve shell fragment

$\square$ Scaphignathus $\square$ Alternognathus $\square$ Branmehla $\square$ Clydagnathus $\square$ Pandorinellina $\square$ Neopolygnathus
Pseudopolygnathus

Figure 5 Conodont biofacies of the Baqer-Abad section. Sea-level changes according to Sandberg et al. (2002) and Joachimski et al. 
Polygnathus glaber glaber, and Scaphignathus velifer velifer. Ecology: The conodont biofacies contains scaphignathids and bispathodids, typical for the tidal flat part of the basin - the very shallow water environment.

\subsection{UPPERMOST MARGINIFERA-TRACHYTERA INTERVAL ZONE}

This zone is recognized in the interval between 95 and $125 \mathrm{~m}$, and includes package 6 and the lower part of package 7 (samples P14-P16). The interval zone contains thin-bedded fossiliferous grey limestone with abundant brachiopods, corals, gastropods, and tentaculites. The lower boundary is defined by the first occurrence of Scaphignathus velifer velifer, which is the index taxon for determining the zone. Some other important conodonts in this zonal association are Bispathodus stabilis vulgaris, Polygnathus padovani, Polygnathus glaber glaber, and Polygnathus nodocostatus nodocostatus. The upper boundary of this interval zone is recognized by the disappearance of zonal association Scaphignathus velifer velifer, Polygnathus padovani, and Polygnathus glaber glaber. Ecology: This conodont biofacies contains scaphignathids, bispathodids, and polygnathids, which inhabit the zone between the tidal flat part of the basin and the lagoon - a shallow water environment.

\subsection{POSTERA ZONE}

The interval between 125 and $155 \mathrm{~m}$ from the base of the section, package 7 (samples P16-P19) is related to the postera Zone. This zone includes thin-bedded fossiliferous grey limestone with abundant brachiopods, corals, gastropods, and tentaculites in package 7 and grey to black platy shale with no fossil contents in package 8 . The low diversity of conodonts does not allow subdividing this zone into two portions, Lower postera and Upper postera yet. Because of the lack of the index taxon Palmatolepis perlobata postera as marker of the lower boundary, we propose the first appearance of Bispathodus stabilis as well as Palmatolepis gracilis expansa as markers for the upper boundary of the postera Zone. The only species with range in this zone are Alternognathus regularis regularis and Polygnathus perplexus. Clydagnathus ormistoni occurs in the upper part of the zone and continues into

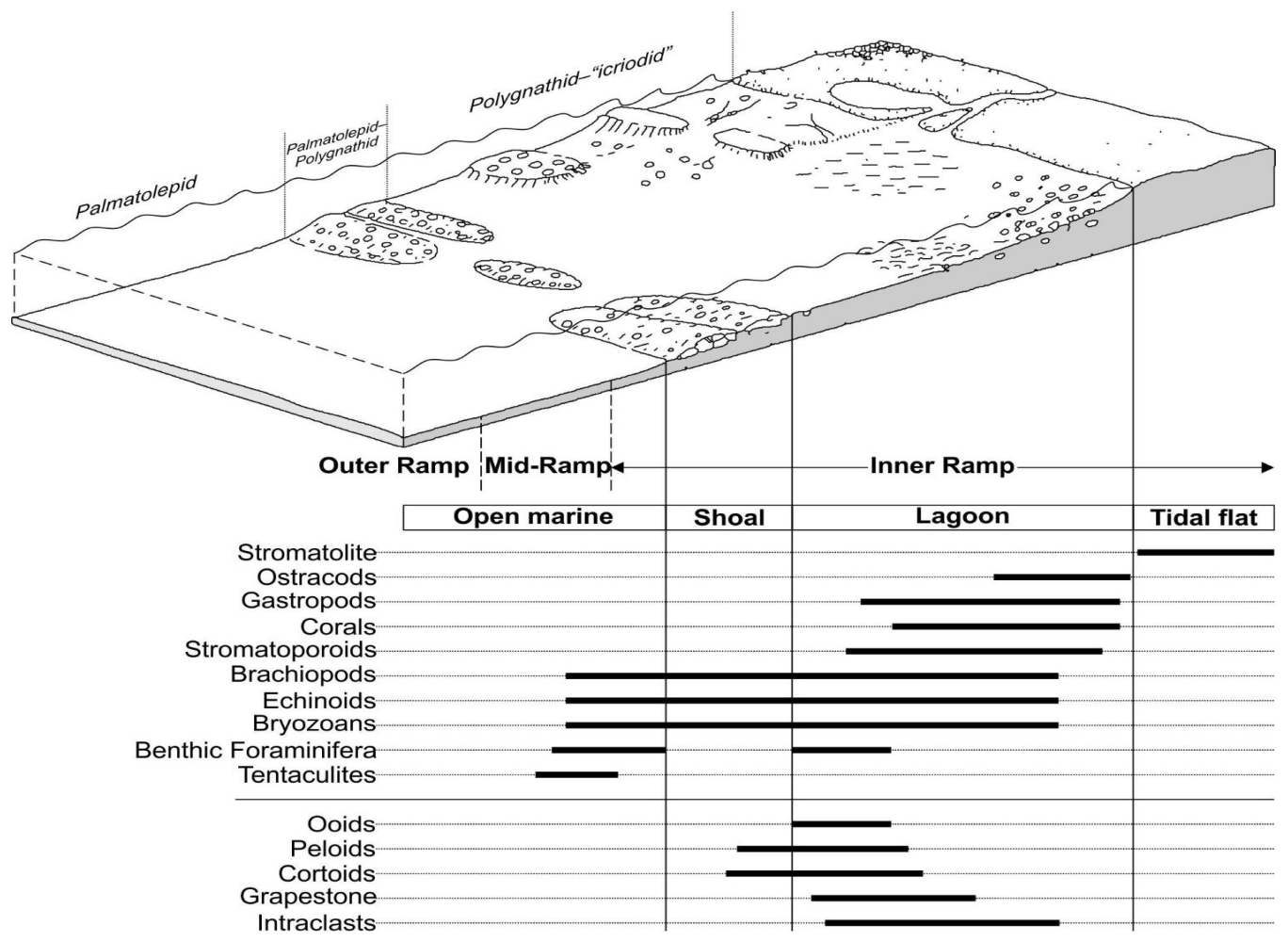

Figure 6 Paleogeographic reconstruction of Late Devonian sedimentary basin recorded at Baqer-Abad section. 
the overlaying zone. Ecology: Typical shallow water conodont biofacies on the basis of cladygnathids, bispathodids, and alternognathids, and the presence of palmatolepids can be presumably explained by some kind of transportation from different environments.

\subsection{EXPANSA ZONE}

According to the original definition of the expansa Zone in Ziegler and Sandberg (1990) this zone can be subdivided into three parts: Lower, Middle, and Upper. The Baqer-Abad section shows high diversity in conodont content from the expansa Zone and allows reliable comparison and correlation with the new zonal divisions using the distribution of Bispathodus species (Becker et al., 2016; Spalleta et al., 2017), which are concurrent with lower expansa, middle expansa, and upper expansa zones (Ziegler and Sandberg ,1990). The Baqer-Abad section has potential for correlation and we subdivide expansa zone into three parts: lower - corresponding to stabilis Zone, middle - corresponding to aculeatus Zone, and upper expansa zone - coinciding with ultimus Zone (Becker et al., 2016; Spalleta et al., 2017).

\subsection{LOWER EXPANSA ZONE}

Lower expansa Zone (correlated with stabilis Zone) includes the sediments between 155 and $175 \mathrm{~m}$ from the base of the section and incorporates package 9 represented by thin-bedded fossiliferous grey sandy limestone with abundant brachiopods, corals, gastropods, and tentaculite, and the lower part of package 10 (samples P19-P23). The lower part of the zone comprises thick- to medium- bedded fossiliferous grey limestone with alternation of grey to green shale (in package 10) rich in brachiopods, corals, crinoid stems, gastropods, and tentaculites. The lower limit of this zone is determined by the first occurrence of Bispathodus stabilis as well as Palmatolepis gracilis expansa. The upper boundary is recognized by the first appearance of Bispathodus aculeatus aculeatus. Taxa with occurrence in this zone are Polygnathus semicostatus, Branmehla fissilis, Bispathodus jugosus, and Palmatolepis gracilis sigmoida- lis, but continue into the overlying Middle expansa Zone. Only Clydagnathus ormistoni disappears at the end of this zone. Ecology: The presence of clydagnathids, palmatolepids, polygnathids, and bispathodids can be related to the eustatic fluctuations of sea level and corresponds to tidal flat zone - more shallow water condition or transport of different environments and conjunct fauna.

\subsection{MIDDLE EXPANSA ZONE}

This zone is recognized in the interval between 175 and $185 \mathrm{~m}$ from the base of package 10 (samples P23-P26), and includes thick to medium bedded fossiliferous grey limestone with alternation of grey to green shale including brachiopod, coral, crinoid stem, gastropod, and tentaculite.

The lower boundary of the Middle expansa Zone is characterized by the first appearance of Bispathodus aculeatus aculeatus. According Becker et al. (2016) and Spalleta et al. (2017), the appearance of Bispathodus aculeatus aculeatus determines of the aculeatus Zone. Having enough varied and rich conodont fauna in the studied section we found, together with the first occurrence of the index taxon, Bispathodus costatus costatus, Polygnathus granulosus, Bispathodus spinilicostatus, and Polygnathus delicatulus. The upper boundary of the Middle expansa Zone is defined by the first appearance of Bispathodus ultimus and Palmatolepis gracilis gracilis. Ecology: Typical shallow water conodont biofacies on the base of bispathodids, polygnathids presence as well as macrofauna including brachiopod, coral, and crinoid stems.

\subsection{UPPER EXPANSA ZONE-PRAESULCATA INTERVAL ZONE}

This interval zone comprises the sediments between 185 and $220 \mathrm{~m}$ (P26-P30), and includes the upper part of package 10 and packages 11,12 , and 13 , which represented by grey to green platy shale, fine-grained sandstone and medium-bedded dolomitic limestone with gastropod, brachiopod, and coral segments. Species such as Palmatolepis gracilis gracilis and Bispatodus ultimus have first occur- 


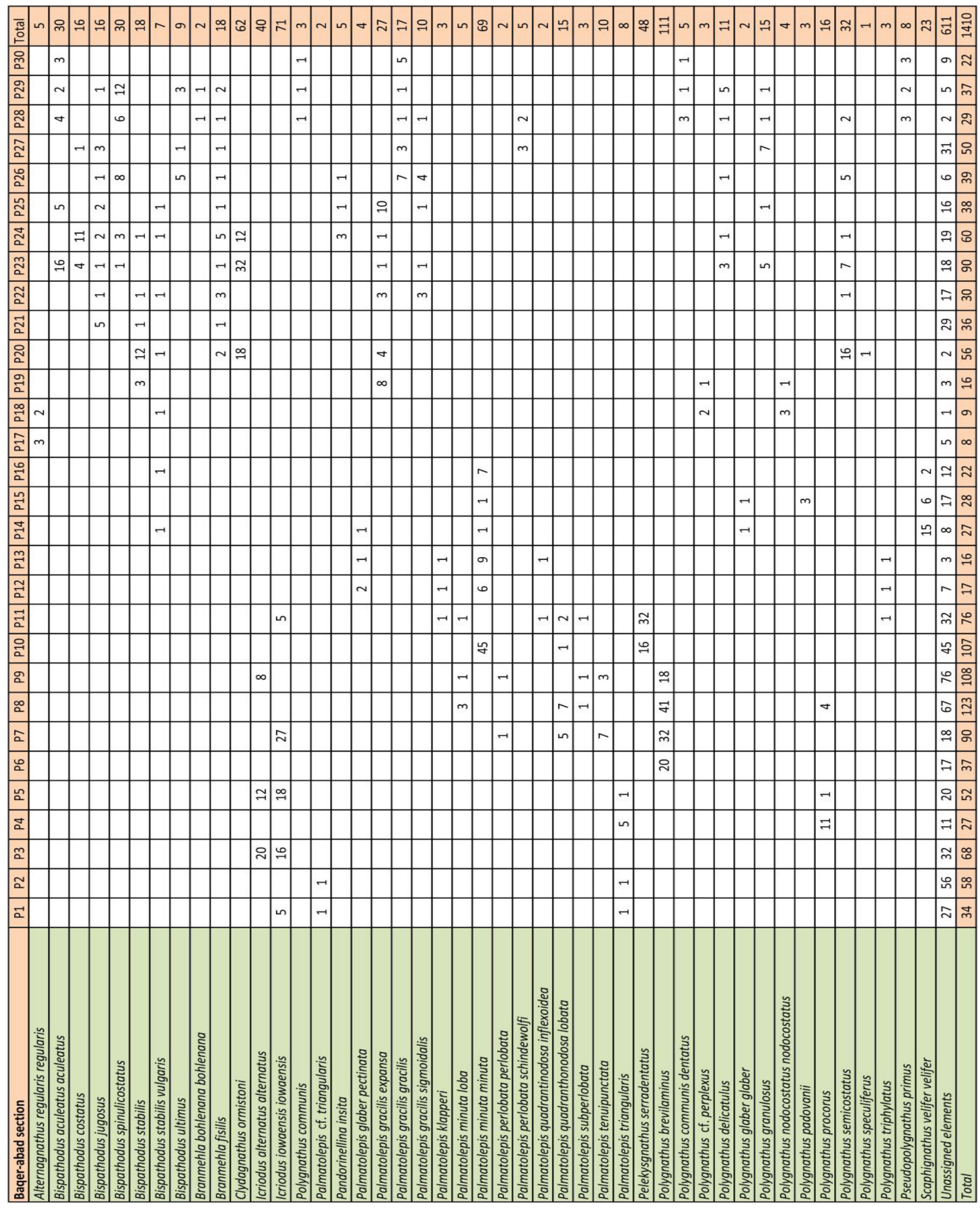


rence at the base of the zone and determinate its lower boundary. The stratigraphic distribution of Palmatolepis perlobata schindewolfi and Bramehla bohlenana bohlenana have been recorded only in this zone. The following species appear a little above the lower boundary of the zone: Bramehla bohlenana bohlenana, Pseudopolygnathus primus, Polygnathus communis communis, and Polygnathus communis dentatus. Taxa having range from underlying zonal interval and disappear at the lowermost part of Upper expansa Zone-praesulcata Zone are: Pandorinellina insita, Bispathodus stabilis vulgaris, and Palmatolepis gracilis expansa. Continuing their distribution from the underlying zone are the following taxa: Bispathodus aculeatus aculeatus, Polygnathus semiccostatus, Bispathodus jugosus, Polygnathus delicatulus, Bispathodus spinilicostatus, Polygnathus granulosus, and Bramehla fissilis. This association includes species disappearing in the lower part of the zone but demonstrate impressive variety. The Devonian sediments are disconformably overlain by red marly sandstone, limestone, and dolomitic limestone of the Permian Jamal Formation. (Figures 5, 6 and 7)To define the next missing zonal interval in the study section it is necessary to obtain more informative conodont associations close to the uppermost part of the Famennian and the boundary with the Carboniferous.

\section{Conclusions}

The Late Devonian shallow-water sedimentation inherited the Middle Devonian carbonate platform conditions and repeats the conducive conditions for prosperous organism communities. Paleoecological interpretations of Famennian conodonts established in northeastern Isfahan are applicable to a shallow-water regime in the basin where different type of limestones dominate. Mixed conodont biofacies are frequent in packages 1 and 2 where palmatolepids, polygnathids, icriodids, and pelekysgnathids are found together in association, corresponding to ages of the triangularis and the crepida zones. Both biozones are related to inner-ramp settings as upper-slope and shelf environments. The change of microenvironment affects biofacies in the rhomboidea Zone and the Lower marginifera Zone (Becker et al., 2016; Spalleta et al., 2017), and they are dominated by polygnathid-palmatolepid, typical for upper slope in inner-ramp conditions. The conodont biofacies in the upper boundary of the Late marginifera (barren) Zone, as well as in the Uppermost marginiferatrachytera interval Zone contains scaphignathids and bispathodids, typical for the tidal flat part of the basin. The very shallow-water environment explains the lack of macrofossils. The mixed conodont biofacies in the postera Zone on one hand show typical shallow-water sedimentary conditions on the base of cladygnathids, bispathodids, and alternognathids, but on the other hand, the presence of palmatolepids presumably leads to the idea that some kind of transportation from a different environment happened. Packages 9, 10, 11, 12, and 13 are related to the Lower expansa Zone, Middle expansa Zone and Upper expansa Zone-praesulcata Zone, where the presence of clydagnathids, palmatolepids, polygnathids, and bispathodids can be related to the eustatic fluctuations of sea level and corresponds to tidal flat zone - where more shallow water or transport of different portions of water and their conjunct fauna refresh the habitat. The Middle-Upper Devonian carbonate platform succeeded keeping favorable conditions for macrofaunal habitats and conodonts. The shallow-water environment favors the joint existence of polygnathid-icriodid and palmatolepid-polygnathid biofacies in diversity and abundance. Baqer-Abad conodont data enable us to better interpret the stratigraphic range of the Bahram Formation in central Iran.

\section{Acknowledgements}

We thank both anonymous reviewers for their constructive comments. The authors thank the University of Isfahan, IR Iran, for financial and logistic support. 


\section{References}

Adhamian, A., 2003, Middle Devonian (Givetian) conodont biostratigraphy in the Soh area, north of Esfahan, Iran: Courier Forschungsinstitut Senckenberg, 245, 183-193.

Bahrami, A., Boncheva, I., Königshof, P., Yazdi, M., Ebrahimi Khan-Abadi, A., 2014, Conodonts of the Mississippian/Pennsylvanian boundary interval in Central Iran: Journal of Asian Earth Sciences, 92,187-200. https:// doi.org/10.1016/j.jseaes.2014.06.017

Bahrami, A., Königshof, P., Boncheva, I., Tabatabaei, M.S., Yazdi, M., Safari, Z., 2015, Middle Devonian (Givetian) conodonts from the northern margin of Gondwana (Soh and Natanz regions, northwest Isfahan, Central Iran): biostratigraphy and palaeoenvironmental implications: Palaeobiodiversity and Palaeoenvironments, 95(4), 555-577. https://doi.org/10.1007/ s12549-015-0205-0

Bahrami, A., Königshof, P., Boncheva, I., Yazdi, M., Ahmadi Nahre Khalaji, M., Zarei, M., 2018, Conodont biostratigraphy of the Kesheh and Dizlu sections, and the age range of the Bahram Formation in central Iran: Palaeobiodiversity and Palaeoenvironments, 98, 315-329. https://doi.org/10.1007/ s12549-017-0307-y.

Becker, R. T., Königshof, P., Brett, C.E.(Eds.)., 2016, Devonian climate, sea level and evolutionary events: an introduction: Geological Society of London, Special Publication, 432, 1-10. https://doi.org/10.1144/SP423.15.

Berberian, M., King, G.C.P., 1981, Towards a paleogeography and tectonic evolution of Iran: Canadian Journal of Earth Sciences, 18, 210-265. https://doi.org/10.1139/e81-019

Beinert, R.J., Klapper, G., Sandberg,C.A. and Ziegler,W., 1971, Revision of Scaphignathus and description of Clydagnathus? ormistoni n. sp. (Conodonta, Upper Devonian): Geologica et Palaeontologica 5, 81-91.

Bischoff, G. 1957. Die Conodonten-Stratigraphie des rhenohersynischen Untercarbons mit
Berücksichtigung der WocklumeriaStufe und der Devon/Karbon Grenze: Abhandlungen des Hessischen Landesamtes für Bodenforschung 19, $64 \mathrm{p}$.

Boncheva, I., Bahrami, A., Yazdi, M., Torabi, H., 2007, Carboniferous conodont biostratigraphyandlatePaleozoicdepositional evolution in South Central Iran (AsadAbad section - SE Isfahan): Revista Italina Paleontologia Stratigrafia, 113, 329-356. https://doi.org/10.13130/2039-4942/5879

Branson, E. R., 1934, Conodonts from the Hannibal Formation of Missouri: The University of Missouri Studies, 8(4): 301-343. Branson, E.B., and Mehl, M.G., 1934, Conodonts from the Grassy Creek Shale of Missouri. The University of Missouri Studies 8, 171-259.

Brice, D., Kebriaee, M., 2000, New species of Leiorhynchiidae Rhynchonellid brachiopod from the Frasnnian of Chahriseh, Isfahan province, Central Iran: Annales de la Sociètè Géologique du Nord, 8, 61-66.

Brice, D., Yazdi, M., Torabi, H., Maleki, M., 2006, Devonian brachiopods from the Zefreh section (Central Iran): Annales de la Société Géologique du Nord, T.13, 141-155.

Çapkınoğlu Ş., 1991, A new Pelekysgnatus species from the Lower Famennian of the Taurides: Turkey. Bollettino della Società Paleontologica Italiana 30, 349-353.

Clausen, C. D., Weddige, K., Ziegler, W., 1993, Devonian of the Rhenish Massif: Subcommission on Devonian Stratigraphy, Newsletter 10, 18-19.

Djafarian, M.A., 2000, Late Devonian index brachiophoda of northeast Isfahan in correlation with other regions: Journal of Sciences, 11, 221-231.

Djafarian, M. A., Brice, D., 1973, Biostratigraphie des brachiopodes dans le Famennien supérieur de la région d'Ispahan (Iran central): Comptes Rendus de l'Academie des Sciences, 276, 2125-2128.

Druce, E., 1969, Devonian and Carboniferous conodonts from the Bonaparte Gulf Basin, northern Australia and their use in 
international correlation. Bureau of Mineral

Resources, 98, 1-242.

Ernst, A., Königshof, P., Bahrami, A., Yazdi, M., Boncheva, I., 2017, A Late Devonian (Frasnian) bryozoan fauna from central Iran: Palaeobiodiversity and Palaoenvironments, 97, 541-552. https://doi.org/10.1007/ s12549-016-0269-5.

Flügel, E., 2004, Microfacies of carbonate rocks. Analysis, Interpretation and Application: Springer Verlag, Berlin Heidelberg, 976 p.

Ghavidel-Syooki, M., 2001, Palynostratigraphy and palaeogeography of the Late Devonian strata in northeastern Esfahan city, Central Iran in Proceeding of the IX International Palynology Congress, Houston, Texas, 1996: USA, American Association of Stratigraphic Palynologists Foundation, 37-51.

Gholamalian, H., 1997, Biostratigraphy of the Lare Devonian succession based on conodonts and microvertebmtes in the Chahriseh area, NE 1sfahan, Central lran: Iran, University of lsfahan. Master Thesis, 137p.

Gholamalian, H., 1998, Biostratigiaphy of the late Devonian sediments based on conodont spccies in the Chahriseh area. northeast of Esfahan. in Mawson R., Talent J., Wilson C., UNESCO-IGCP Project No, 421, the Condwanan mid-Palaeozoic bioeventôiogeography pattem in relation to crustal dynamics. Esfahân meeting, 5-20.

Gholamalian, H., Turner, S., Burrow, C.J., Yazdi, M., 2000, Recovery of Late Devonian (Frasnian) microvertebrates and Conodonts from the Chahriseh area, northeast Isfahan, Iran, in: Wilson, G., \& Lauri, J., (eds.), abstract book. Sydney meeting of AUSCOS-2.

Gholamalian, H., 2003, Age-implication of Late Devonian conodonts from the Chah-Riseh area, northeast of Esfahan, central Iran; Courier Forschungsinstitut Senckenberg, 256, 201-207.

Gholamalian, H., 2007, Conodont biostratigraphy of the Frasnian-Famennian boundary in the Esfahan and Tabas areas, Central Iran: Geological Quarterly, 5, 453-476.
Ghobadipour, M., Popov, L. E., Hosseini, M., Adhamian, A., Yazdi, M., 2013, Late Devonian (Frasnian) trilobites and brachiopods from Soh area, Central Iran: Memoire Association Australian Paleontologist, 44, 149-158.

Habibi, T., Yazdi, M., Zarepoor, S., Parvanehnejad Shirazi, M., 2013, Late Devonian Fish micro-remains from Central Iran: Journal of Geopesia, 3(1), 25-34. https://doi.org/10. 22059/JGEOPE.2013.31929

Hairapetian, V., Yazdi, M., Long, J.A., 2000, Devonian vertebrate biostratigraphy of Central Iran: Records of the Western Australian Museum, Supplement, 58, 241-247.

Hamedani, A., 1996, Neue biostratigraphische Daten aus demPaläozoikum (Devon-Karbon) von Isfahan, Iran: Neues Jahrbuch für Geologie und Paläontologie, Monatshefte, 5, 309-323.

Hartenfels, S., 2011, Die globalen AnnulataEvents und die Dasberg-Krise (Famennium, Oberdevon) in Europa und Nord-Afrika hochauflösende Conodonten-Stratigraphie, Karbonat-Mikrofazies, Paläoökologie und Paläodiversität: Münstersche Forschungen zur Geologie und Paläontologie, 105, 17-527.

Helms, J., 1959, Conodonten aus dem Saalfelder Oberdevon (Thuringen): Geologie 8, 634-677.

Joachimski, M.M, VanGeldern, R., Breisig, S., Buggisch, Day, J., 2004, Oxygen isotope evolution of biogenic calcite and apataite during the Middle and Late Devonian: International Journal of Earth Science, 93, 542-553. https://doi.org/10.1007/ s00531-004-0405-8

Klapper, G. \& Ziegler, W., 1979, Devonian conodont biostratigraphy, in HOUSE, M.R., Scrutton, C.T. \& Bassett, M.G. (eds) The Devonian System. Special Papers in Paleontology 23, 199-224.

Königshof, P., Carmichael, S.K., Waters, J., Jansen, U., Bahrami, A., Boncheva, I. Yazdi, M., 2017, Palaeoenvironmental study of the Palaeotethys Ocean: The GivetianFrasnian boundary of a shallow-marine 
environment using combined facies analysis and geochemistry (Zefreh Section/ Central Iran), in B. Mottequin, L. Slavik, \& P. Königshof (Eds.), Climate change and biodiversity patterns in the mid-Paleozoic: Palaeobiodiversity and Palaeoenvironments, 97(3), 517-540.

Leven E.J., Gorgij M.N., 2008, New fusulinids of the Moscovian Stage found in Iran: stratigraphy geological correlation, 16(4),164-173. https:// doi.org/10.1134/S0869593808040035

Leven, E.J., Gorgij, M.N., 2011 a, First record of Gzhelian and Asselian fusulinids from the Vazhnan Formation (Sanandaj-Sirjan Zone of Iran): stratigraphy geological correlation, 19(5), 486-501. https://doi.org/10.1134/ S0869593811050066

Leven, E.J., Gorgij, M.N., 201 1b, Fusulinids and stratigraphy of the Carboniferous and Permian in Iran: stratigraphy geological correlation, 19(7), 687-776. https://doi. org/10.1134/S0869593811070021

Mistian, B., Gholamalian, H., 2000, Stromatoporoids and some tabulate corals from Chahriseh area (Isfahan province, Central Iran): Annales de la Société géologique du Nord, 8, 81-91.

Mistiaen, B., Gholamalian, H., Gourvennec, R., Plusquellec, Y., Bigey, F., Brice, D., Feist, M., Feist, R., Ghobadipour, M., Kebriaei, M., Milhau, B., Nicollin, J. P., Rohart, J. C., Vachard, D., Yazdi, M., 2000, Preliminary data on the Upper Devonian Frasnian, Famennian and Permian fauna and flora from the Chahriseh are Esfahan province, central Iran: Annales de la Sociètè gèologique du Nord, 8, 93-102.

Müller, K. J., 1956, Zur Kenntnis der ConodontenFauna des europäischen Devons, 1: Die Gattung Palmatolepis: Abhandlungen der Senckenbergischen Naturforschenden Gesellschaft, 494, 1-70.

Müller, K.J., and Müller, E.M., 1957, Early Upper Devonian (Independence) Conodonts from Iowa, part I: Journal of Paleontology, 31(6), 1069-1108.
Perri, M.G., and Spalletta, C., 1990, Famennian conodonts from climenid pelagic limestone, Carnic Alps, Italy: Palaeontographia Italica, 77, 55-83.

Radfar, J., Kohansal, R., 2002, Geological map of Iran (Kuhpayeh) 1:100000, Sheet 6455: Geological Survey and Mineral Exploration of Iran, Tehran.

Ruban, D.A., Al-Husseini, M.I., Iwasaki, Y., 2007, Review of Middle-east Paleozoic plate tectonics: GeoArabia, 12, 35-56.

Safari, A., Kangazian, A., 2003, Microfacies and sedimentary environment of Upper Devonian sedimentary rocks in the Chahriseh area (in Persian with English abstract): Research Bulletin of Isfahan University (Science), 18, 117-144.

Sandberg, C. A. \& Ziegler, W., 1979, Taxonomy and biofacies of important conodonts of Late Devonian styriacus-Zone, United States and Germany: Geologica et Palaeontologica, 13, 173-212.

Sandberg, C.A., Morrow, J.R., Ziegler, W., 2002, Late Devonian sea-level changes, catastrophic events, and mass extinctions, in Koeberl, C., \& MacLeod, K.G. (eds.), Catastrophic Event and Mass Extinctions: Impacts and Beyond: Geological Society of America Special Paper, 356, 473-487. https://doi.org/10. 1130/0-8137-2356-6.473.

Sannemann, D., 1955, Beitrag zur Untergliederung des Oberdevons nach Conodonten: Neues Jahrbuch für Geologie und Paläontologie, Abhandlungen, 100, 324-331.

Scotese, C.R., 2001, Atlas of Earth history Paleogeography (Vol. 1). In PALEOMAP Progress Rep. 90-0497. Department of Geology, University of Texas, Arlington.

Sharland, P.R., Archer, R., Casey, D.M., Davies, R.B., Hall, S.H., Heward, A.P., Horbury, A.D., Simmons, M.D., 2001, Arabian Plate sequence stratigraphy: Geo.Arabia Special Publication 2: Manama, Bahrain, Gulf Petrolink, $372 \mathrm{p}$.

Shirani, K., 1995, Palinostratigraphy and paleobiogeography of the Late Devonian sediments in the Chah-Riceh area, NE 
Isfahan, Gentral Iran: Tehran, Iran, Sadra University, Master Thesis, 235 p.

Soffel, H. C., Förster, H. G., 1984, Polar wander path of the Central- East-Iran Microplate including new results: Neues Jahrbuch für Geologie und Paläontologie, Abhandlungen, 168(2/3), 165-172. https:// doi.org/10.1127/njgpa/168/1984/165

Spalleta, C. Perri, M.C, Jeffrey over, D., Corradini, C., 2017, Famennian (Upper Devonian) conodont Zonation: revised global standard. 92, 31-57, DOl 10.3140/bull.geosci. 1623

Stöcklin, J., 1968, Structural history and tectonics of Iran: a review: American Association of Petroleum Geologists Bulletin, 52(7), 1229-1258.

Thomas, L.A. 1949, Devonian-Mississippian Formations of southeast Iowa. Bulletin of the Geological Society of America 60, 403-138. Turner, S., Burrow, G.J., Gholamalian, H., Yazdi, M., 2002, Late Devonian (Early Frasnian) microvertebrates and Conodonts from the Chahriseh area near Isfahan, Iran: Memoirs of the Association of Australian Palaeontologist, 27, 149-159.

Ulrich, E.O., and Bassler, R.S., 1926, A classification of the tooth-like fossils, conodonts, with descriptions of American Devonian and Mississippian species: Proceedings of the United States National Museum 68, 1-63. https://doi.org/10. 5479/si.00963801.68-2613.1

Webster, G.D., Maples, G.G., Yazdi, M., 2007, Late Devonian and Early Mississippian Echinoderms from central and northern Iran: Journal of Paleontology, 81, 1101-1113. https://doi.org/10.1666/pleos05-151.1

Weddige, K., 1984a, Externally controlled late Paleozoic events of the Iran Plate: Neues Jahrbuch für Geologie und Paläontologie, Abhandlungen, 168, 278-286. https://doi. org/10.1127/njgpa/168/1984/278

Weddige, K., 1984b, Zur Stratigraphie und Paläogeographie des Devons und Karbons von NE Iran: Senckenbergiana lethaea, 65, 179-223.
Wendt, J., Kaufmann, B., Belka, Z., Farsan, N., Karimi-Bavandpour, A., 2002, Devonian/ Lower Carboniferous stratigraphy, facies pattern and paleogeography of Iran. Part I. Southeastern Iran: Acta Geologica Polonica, 52, 129-168.

Wendt, J., Kaufmann, B., Belka, Z., Farsan, N. and Karimi Bavandpur, A., 2005, Devonian/ Lower Carboniferous stratigraphy, facies patterns and palaeogeography of Iran. Part II. Northern and Central Iran: Acta Geologica Polonica, 55 ,31-97.

Yazdi, M., 1996, Late Devonian-Carboniferous Conodont biostratigraphy of the Tabas area, Eastern Iran: Sydney, Macquarie University, $\mathrm{PhD}$ dissertation, $221 \mathrm{p}$.

Yazdi, M., Ghobadipour, M. and Mawson, R., 2000, Late Devonian conodonts from the Chahriseh area, central Iran: Records of the Western Australian Museum Supplement, 58, 179-189.

Youngquist, W.L., and Peterson, R.F., 1947, Conodonts from the Sheffield Formation of north-central Iowa: Journal of Paleontology 21, 242-253.

Zahedi, M., 1973, Etude geologique de La region de Soh (W de Iran central): Geological survey of Iran, Tehran, 27, 197 p.

Zahedi, M., 1976, Explanatory text of the Esfahan quadrangle map F8, scale 1: 250000: Geological Survey of Iran, map with text.

Ziegler, W., 1962, Taxionomie und Phylogenie Oberdevonischer Conodonten und ihre stratigraphische Bedeutung: Abhandlungen des Hessischen Landesamtes für Bodenforschung, 38, 166 p.

Ziegler, W., Sandberg, C.A., 1984, Palmatolepis based revision of upper part of standard Late Devonian Conodont zonation: Geological Society of America, Special Papers, 196, 179-194. https://doi.org/10.1130/ SPE196-p179

Ziegler, W., Sandberg, C.A., 1990, The Late Devonian Standard Conodont Zonation: Courier Forschungsinstitut Senckenberg, $121,1-115$. 


\section{Appendix}
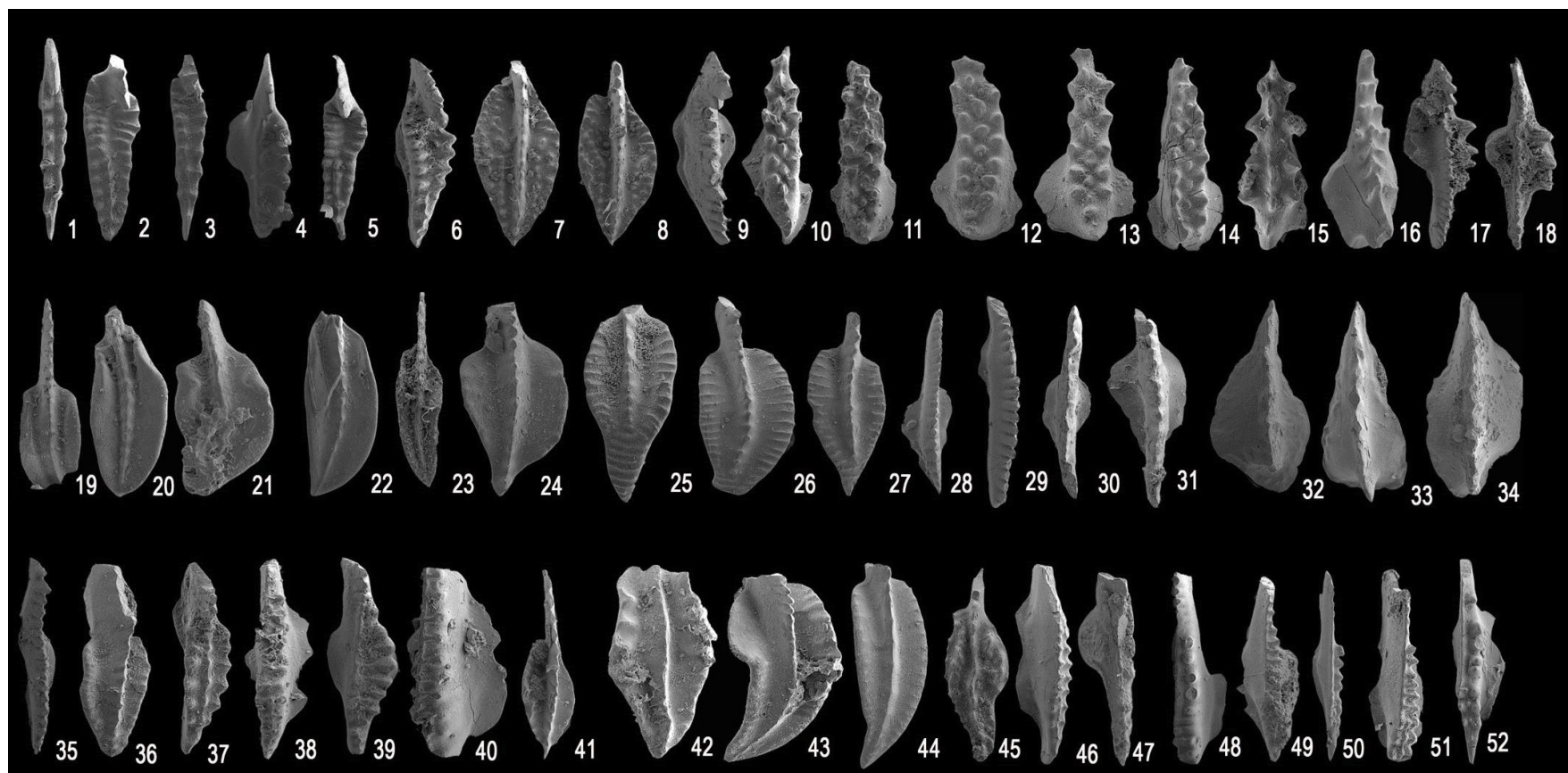

Figure 8 Photographs of conodonts from the Baqer-Abad section, Northeast Isfahan. $(1,3)$ - Scaphignathus velifer velifer HELMS 1959 morphotype 1; (1) Upper view, EUIC P100, Sample P 14, X 70. (3) Upper view, EUIC P102, Sample P 15, X 70. $(2,5,6)$ Scaphignathus velifer velifer HELMS 1959 morphotype 2; (2) Upper view, EUIC P101, Sample P 15, X 70. (5) Upper view, EUIC P103, Sample P 16, X 75. (6) - Upper view, EUIC P103, Sample P 16, X 75. (4) - Clydagnathus ormistoni BEINERT, KLAPPER, SANDBERG and ZIEGLER 1971; Upper view, EUIC P105, Sample P 20, X 75. (7, 8) - Polygnathus granulosus BRANSON and MEHL 1934; (7) - Upper view, EUIC P106, Sample P 25, X 80. (8) Upper view, EUIC P106, Sample P 27, X 80. (9) - Pandorinellina insita MÜLLER and MÜLLER 1957; Upper view, EUIC P108, Sample P 25, X 80. (10-14) - Icriodus alternatus alternatus BRANSON and MEHL 1934; (10) - Upper view, EUIC P109, Sample P 3, X 70; (11) - Upper view, EUIC P1 10, Sample P 3, X 70; (12) - Upper view, EUIC P111, Sample P 5, X 70; (13)- Upper view, EUIC P1 12, Sample P 7, X 70; (14) - Upper view, EUIC P1 13, Sample P 5, X 70. (15) - Icriodus cornutus SANNEMANN 1955; Upper view, EUIC P1 14, Sample P 3, X 70. (16, 40) - Icriodus iowaensis iowaensis YOUNGQUIST and PETERSON 1947; (16) - Upper view, EUIC P115, Sample P 1, X 70; (40)- Upper view, EUIC P116, Sample P 7, X 80. (17-18) - Bispathodus aculeatus aculeatus (BRANSON and MEHL, 1934); (17)- Upper view, EUIC P117, Sample P 28, X 70; (18) - Upper view, EUIC P1 18, Sample P 29, X 70. (19, 22)- Polygnathus communis communis BRANSON and MEHL 1934; (19) - Upper view, EUIC P1 19, Sample P 28, X 70; (22)- Upper view, EUIC P120, Sample P 29, X 75. (20 - 21) - Polygnathus communis dentatus DRUCE 1969; (20) - Upper view, EUIC P121, Sample P 28, X 70; (21) - Upper view, EUIC P122, Sample P 29, X 80. (23, 43) - Polygnathus padovanii PERRI and SPALLETTA 1990; (23)- Upper view, EUIC P123, Sample P 15, X 70; (43) - Upper view, EUIC P124, Sample P 15, X 90. (24) - Polygnathus glaber glaber ULRICH and BASSLER 1926; Upper view, EUIC P125, Sample P 14, X 85. (25 - 27, 44) - Polygnathus semicostatus BRANSON and MEHL 1934; (25) - Upper view, EUIC P126, Sample P 20, X 85; (26) - Upper view, EUIC P127, Sample P 22, X 90; (27) - Upper view, EUIC P128, Sample P 24, X 70; (44) - Upper view, EUIC P129, Sample P 26, X 80. (28, 29, 35) - Bispathodus stabilis (BRANSON and MEHL 1934), Morphotype 1; (28) - Upper view, EUIC P130, Sample P 19, X 70; (29) - Upper oblique view, EUIC P131, Sample P 20, X 75; (35) - Upper view, EUIC P134, Sample P 25, X 70. (30, 31) - Bispathodus stabilis vulgaris DZIK 2006; (30) - Upper view, EUIC P132, Sample P 22, X 70; (31) - Upper view, EUIC P133, Sample P 24, X 75. (32-34) - Peleksgnathus serradentatus ÇAPKINOGLU 1991; (32) - Upper view, EUIC P135, Sample P 10, X 75; (33) - Upper view, EUIC P134, Sample P 11, X 75; (34) - Upper view, EUIC P137, Sample P 11, X 80. (36) - Polygnathus procerus SANNEMANN 1955; Upper oblique view, EUIC P138, Sample P 8, X 70. (37) - Alternognathus regularis regularis ZIEGLER and SANDBERG 1984; Upper view, EUIC P139, Sample P 18, X 70. (38) - Bispathodus ultimus BISCHOFF 1957; Upper view, EUIC P140, Sample P 29, X 70. (39) - Bispathodus spinilicustatus BRANSON 1934; Upper view, EUIC P141, Sample P 29, X 75. (41) - Polygnathus delicatulus ULRICH and BASSLER 1926; Upper view, EUIC P142, Sample P 29, X 70. (42) - Polygnathus sp.; Upper view, EUIC P143, Sample P 24, X 90. (45) - Polygnathus spiculiferus HARTENFELS 2011 Morphotype 2; Upper view, EUIC P144, Sample P 20, X 70. (46, 51-52) - Bispathodus costatus BRANSON 1934; (46)- Upper view, EUIC P145, Sample P 23, X 70; (51) - Upper view, EUIC P146, Sample P 24, X 70; (52) - Upper view, EUIC P147, Sample P 27, X 70. (47, 50) - Bispathodus aculeatus aculeatus (BRANSON and MEHL 1934); (47) - Upper view, EUIC P148, Sample P 29, X 70; (50) - Upper view, EUIC P149, Sample P 30, X 70. (48, 49) - Bispathodus jugosus (BRANSON and MEHL 1934); (48) - Upper view, EUIC P150, Sample P 27, X 70; (49) - Upper view, EUIC P151, Sample P 29, X 70. 


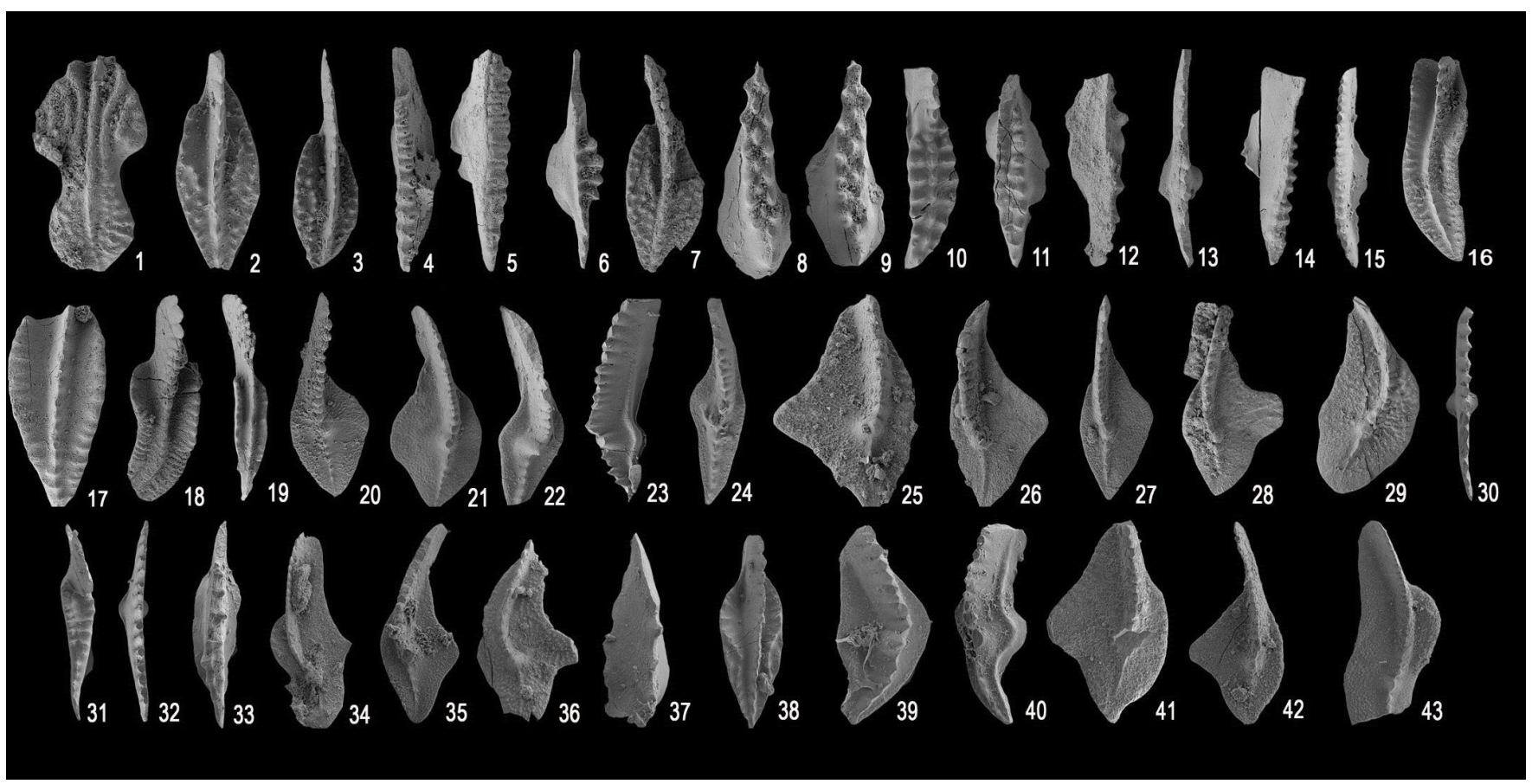

Figure 9 Photographs of conodonts from the Baqer-Abad section, Northeast Isfahan. (1) - Polygnathus triphylatus ZIEGLER 1959; Upper view, EUIC P152, Sample P 12, X 95. (2, 3) - Polygnathus nodocostatus nodocostatus BRANSON and MEHL 1934; (2) - Upper view, EUIC P154, Sample P 18, X 75; (3) - Upper view, EUIC P154, Sample P 18, X 75. (7) - Polygnathus granulosus BRANSON and MEHL 1934; Upper view, EUIC P161, Sample P 29, X 75. (4 ,14) - Bispathodus jugosus (BRANSON and MEHL 1934); (4) - Upper view, EUIC P156, Sample P 27, X 75; (14) - Upper view, EUIC P157, Sample P 29, X 70. (5, 11) - Bispathodus ultimus BISCHOFF 1957; (5) - Upper view, EUIC P158, Sample P 27, X 80; (11) - Upper view, EUIC P159, Sample P 29, X 80. (6, 12) - Bispathodus aculeatus aculeatus (BRANSON and MEHL 1934); (6) - Upper view, EUIC P160, Sample P 29, X 70; (12) - Upper view, EUIC P165, Sample P 30, X 70. (8, 9) - Icriodus alternatus alternatus BRANSON and MEHL 1934; (8)- Upper view, EUIC P162, Sample P 5, X 80; (9) - Upper view, EUIC P163, Sample P 7, X 80. (10) - Scaphignathus velifer velifer HELMS, 1959; Upper oblique view, EUIC P164, Sample P 18, X 75. (13, 15) - Bispathodus stabilis (BRANSON and MEHL 1934), Morphotype 1; (13) - Upper view, EUIC P166, Sample P 22, X 70; (15) - Upper view, EUIC P167, Sample P 24, X 70. (16, 18) - Polygnathus padovanii PERRI and SPALLETTA 1990; (16) - Upper view, EUIC P168, Sample P 15, X 70; (18) - Upper view, EUIC P168, Sample P 15, X 70. (19) - Upper view, EUIC P169, Sample P 15, X 70. (17) - Polygnathus cf. semicostatus BRANSON and MEHL 1934; Upper view, EUIC P170, Sample P 28, $X$ 80. (19) - Polygnathus brevilaminus BRANSON and MEHL 1934; Upper view, EUIC P171, Sample P 9, X 70. (20, 21) - Palmatolepis minuta minuta BRANSON and MEHL 1934; (20) - Upper view, EUIC P175, Sample P 15, X 75; (21) - Upper view, EUIC P176, Sample P 16, X 80. (22, 39) - Palmatolepis gracilis gracilis BRANSON and MEHL 1934; (22) - Upper oblique view, EUIC P178, Sample P 27, X 75; (39) - Upper oblique view, EUIC P220, Sample P 29, X 90. (23, 40) - Palmatolepis gracilis sigmoidalis ZIEGLER 1962; (23) - Upper lateral view, EUIC P182, Sample P 29, X 70; (40) - Upper lateral view, EUIC P222, Sample P 26, X 80. (24) - Palmatolepis gracilis expansa SANDBERG and ZIEGLER 1979; Upper view, EUIC P182, Sample P 29, X 70. (25) - Palmatolepis quadrantinodosalobata SANNEMANN 1955; Upper view, EUIC P183, Sample P 1 1, X 100. (26) - Palmatolepis triangularis SANNEMANN 1955; Upper view, EUIC P185, Sample P 4, X 90. (27) - Palmatolepis minuta loba HELMS 1963; Upper view, EUIC P187, Sample P 11, X 80. (28) - Palmatolepis subperlobata BRANSON and MEHL 1934; Upper view, EUIC P188, Sample P 10, X 80. (29) - Palmatolepis quadrantinodosa inflexoidea, ZIEGLER 1962; Upper view, EUIC P189, Sample P 13, X 90. (30) Branmehla fisilis BRANSON and MEHL 1943; Upper view, EUIC P198, Sample P 28, X 70. (31) - Clydagnathus ormistoni BEINERT, KLAPPER, SANDBERG and ZIEGLER 1971; Upper view, EUIC P199, Sample P 24, X 70. (32) - Branmehla bohlenana bohlenana HELMS 1959; Upper view, EUIC P200, Sample P 29, X 70. (33) - Bispathodus jugosus BRANSON and MEHL 1934; Upper view, EUIC P201, Sample P 29 , X 70. (34) - Palmatolepis perlobata schindewolfi MÜLLER 1956; Upper view, EUIC P202, Sample P 28, X 80. (35) - Palmatolepis minuta minuta BRANSON and MEHL 1934; Upper view, EUIC P211, Sample P 16, X 70. (36) - Palmatolepis perlobata perlobata, ULRICH and BASSLER 1926; Upper view, EUIC P213, Sample P 9, X 80. (37) - Pelekysgnathus serradentatus ÇAPKINOGLU 1991; Upper view, EUIC P214, Sample P 13, X 80. (38) - Polygnathus cf. perplexus THOMAS 1949; Upper view, EUIC P215, Sample P 19, X 80. (41) - Palmatolepis tenuipunctata SANNEMANN 1955; Upper view, EUIC P228, Sample P 9, X 100. (42) - Palmatolepis minuta loba HELMS 1963; Upper view, EUIC P233, Sample P 10, X 90. (43) - Palmatolepis glabra pectinata ZIEGLER 1962; Upper view, EUIC P234, Sample P 14, X 100. 